\title{
Analisis Nilai Tambah dan Penentuan Metrik Pengukuran Kinerja Rantai Pasok Pepaya Calina (Studi Kasus di PT Sewu Segar Nusantara)
}

\author{
Fatih Rizqiah \\ Departemen Manajemen, Fakultas Ekonomi dan Manajemen, \\ Institut Pertanian Bogor \\ Kampus Darmaga Bogor 16680 \\ Alim Setiawan S \\ Departemen Manajemen, Fakultas Ekonomi dan Manajemen, \\ Institut Pertanian Bogor \\ Kampus Darmaga Bogor 16680 \\ e-mail: alimipb@yahoo.co.id
}

\begin{abstract}
The purpose of this study was to analyze the condition of papaya Calina supply chain, to analyze the value-added generated by each member of the Calina papaya supply chain, and to design performance metrics measurement for supply chain members. Hayami method and Analytic Network Process (ANP) are methods used to calculate value-added design and to determine supply chain of Calina papaya's performance measurement metrics. Value of the benefits achieved by farmers is $57.74 \%$, while companies obtain more value for Sunpride (50.7\%) and Sunfresh (55.56\%). As for retail and traditional markets, the value of the benefits is $36 \%$ and value-added is $16.56 \%$. In determining metrics of supply chain performance measurement using ANP, quality (0.274) is considered to be the most influential indicator to determine sustainable supply chain. Quality is percepted to be able to set the price, give satisfaction to consumers and create long-term customer loyalty. Therefore, the farmer as a determinant of quality papaya Calina is a party to the most influential in the supply chain (0.287), leading to economic benefits supply chain in the future.

Keywords : analytical network process, added value, performance measurement, supply Chain
\end{abstract}

\section{ABSTRAK}

Tujuan penelitian ini adalah menganalisis kondisi rantai pasok pepaya Calina, menganalisis nilai tambah yang dihasilkan oleh setiap anggota pada rantaipasokankomoditas pepaya Calina, dan mendesain metrik pengukurankinerja anggota rantai pasokan. Metode Hayami dan Analytic Network Process (ANP) merupakan metode yang digunakan untuk menghitung nilai tambah dan mendesain metrik pengukuran kinerja rantai pasok pepaya Calina. Nilai keuntungan yang diraih oleh mitra tani sebesar $57.74 \%$. Sementara perusahaan mendapatkan nilai tambah sejumlah $50.7 \%$ untuk Sunpride dan $55.56 \%$ untuk Sunfresh. Sedangkan bagi ritel dan pasar tradisional, nilai keuntungan yang diperoleh sebesar 36\% dan nilai tambah sebesar $16.56 \%$. Dalam penentuan metrik pengukuran kinerja rantai pasok menggunakan ANP, indikator yang dirasa paling berpengaruh dalam menentukan sustainable supply chain menurut para pakar adalah kualitas (0.74). Hal ini disebabkan karena kualitas dianggap mampu dalam menentukan tingkat harga, memberikan kepuasan kepada konsumen dan dalam jangka panjang mampu menciptakan loyalitas konsumen. Oleh karena itu, petani sebagai penentu kualitas dan kuantitas pepaya Calina menjadi pihak paling berpengaruh di dalam rantai pasok (0.287), yang berujung pada keuntungan ekonomi rantai pasok kedepannya.

Kata kunci : analytical network process, nilai tambah, pengukuran kinerja, rantai pasok 


\section{Pendahuluan}

Pepaya Calina atau dikenal di pasar dengan nama Pepaya California, merupakan salah satu varietas unggul dari Institut Pertanian Bogor (IPB-9) yang berhasil dikembangkan oleh petani. Nilai ekspor pepaya Indonesia dari US\$15 346 tahun 2007 meningkat menjadi US\$ 514670 tahun 2011 atau berubah rata-rata 5.583\% (Tabel 1). Namun demikian, masih terdapat persoalan yang dihadapi oleh pelaku dalam rantai pasok pepaya Calina yaitu tingginya risiko kerusakan produk selama proses distribusi (mencapai 20\%), distribusi nilai tambah belum proporsional, inefisiensi biaya operasional, dan sebagainya; yang dapat menyebabkan penurunan daya saing pepaya Calina.

Tabel 1. Perkembangan nilai ekspor komoditas buah (dollar)

\begin{tabular}{lcccccc}
\hline \multicolumn{1}{c}{ Komoditas } & $\mathbf{2 0 0 7}$ & $\mathbf{2 0 0 8}$ & $\mathbf{2 0 0 9}$ & $\mathbf{2 0 1 0}$ & $\mathbf{2 0 1 1}$ & Rata-rata Perubahan \\
\hline Pepaya & 15346 & 567 & 125569 & 102951 & 514670 & $5583 \%$ \\
Pisang & 856127 & 988914 & 341037 & 48305 & 1011593 & $465 \%$ \\
Semangka & 232160 & 471082 & 281122 & 25783 & 142937 & $107 \%$ \\
Belimbing & 104 & 190 & 86 & 182 & 1026 & $190 \%$ \\
Durian & 6455 & 84130 & 16239 & 14849 & - & $254 \%$ \\
\hline
\end{tabular}

Sumber: Data Ekspor Impor BPS diolah Direktorat Jenderal Holtikultura (2013)

Manajemen rantai pasok merupakan salah satu pendekatan untuk meningkatkan daya saing. Kegiatan manajemen rantai pasok merupakan bagian kegiatan dari rantai nilai (value chain) sehingga perbaikan manajemen rantai pasok akan berimplikasi positif pada rantai nilai tambah. Rantai nilai yang efektif akan memicu keunggulan nilai (value advantage) dan keunggulan produksi (productivity advantage) yang pada akhirnya meningkatkan keunggulan kompetitif (Simchi-Levi et al 2007). Pendekatan rantai pasok selanjutnya dikembangkan dengan pendekatan keberlanjutan (sustainable supply chain management) yang diharapkan lebih mampu mengoptimalkan kinerja rantai pasok. Hal ini disebabkan karena kelangsungan dan daya saing sebuah organisasi dalam jangka panjang tidak hanya bisa dievaluasi dengan ukuran finansial semata. Investor, pembuat kebijakan, dan pemangku kepentingan yang lain semakin ingin meningkatkan kinerja evaluasi dengan melibatkan aspek keberlangsungan-kinerja lingkungan, sosial, dan ekonomi organisasi (Yakovieva et al 2009).

Salah satu aspek dalam manajemen rantai pasok adalah pengukuran kinerja yang diperlukan sebagai pendekatan dalam rangka mengoptimalisasi jaringan rantai pasokan. Desain metrik pengukuran kinerja yang bertujuan untuk pengukuran kinerja yang mendukung perancangan tujuan, evaluasi kinerja, dan menentukan langkahlangkah ke depan baik pada level strategi, taktik dan operasional (Vorst 2006). Penelitian ini bertujuan untuk menganalisis kondisi rantai pasok pepaya Calina, menganalisis nilai tambah yang dihasilkan oleh setiap anggota pada rantai pasok komoditas pepaya Calina, dan menentukan desain metrik pengukuran kinerja rantai pasok pepaya Calina. 


\section{Metode Penelitian}

Sustainable supply chain management (SSCM)merupakan salah satu pendekatan bertujuan untuk meningkatkan kinerja rantai pasok sekaligus menjaga keberlangsungan rantai pasok melalui pengelolaan aliran material dan informasi serta kerjasama antara pelaku sepanjang rantai pasokan untuk memenuhi target dari semua tiga dimensi pembangunan berkelanjutan, yaitu ekonomi, lingkungan dan sosial masyarakat (Seuring dan Müller 2008). Dalam penelitian ini, kerangka penelitian pada rantai pasok pepaya Calina dengan pendekatan sustainable supply chain dimulai dengan melakukan analisis deskriptif rantai pasok pepaya Calina dengan pendekatan analisis Asian Productivity Organization (APO), analisis nilai tambah rantai pasok pepaya Calina dengan metode Hayami, dan perancangan pengukuran kinerja dengan Analytic Network Process (ANP) (Gambar 1).

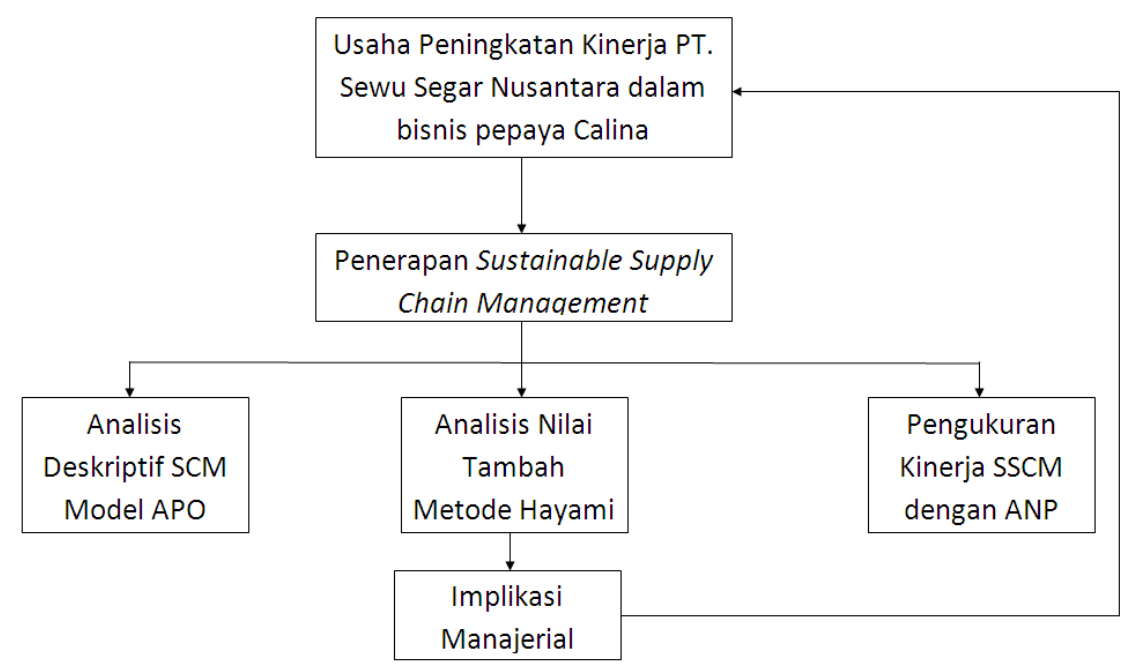

Gambar 1. Kerangka pemikiran penelitian

Pengambilan data dilakukan di PT Sewu Segar Nusantara (PT SSN), di Jalan Telesonic Dalam (Jalan Gatot Subroto KM 8), Desa Kadujaya, Kecamatan Curug, Tangerang, Banten. Pengambilan sampel menggunakan teknik non probability sampling yaitu teknik sampling yang tidak memberikan kesempatan yang sama kepada setiap anggota populasi untuk dijadikan anggota sampel, sehingga penelitian ini menggunakan teknik purposive sampling. Teknik purposive sampling juga digunakan untuk pemilihan pakar yang dilibatkan dalam penelitian. Pertimbangan-pertimbangan yang digunakan untuk menentukan pakar adalah pengalaman pakar dalam bidang yang digelutinya. Pakar-pakar yang dilibatkan dalam penelitian berasal dari kelompok tani, manajer di perusahaan PT SSN, akademisi, dan manajer di perusahaan retail.

1. Analisis Deskriptif Rantai Pasok

Model rantai pasokan papaya Callina dibahas secara deskriptif menggunakan metode pengembangan rantai pasokan produk hortikultura yang dicanangkan oleh APO, Jepang. Metode pengembangan tersebut mengikuti kerangka proses yang telah dimodifikasi oleh Vorst (2006) (Gambar 2). 


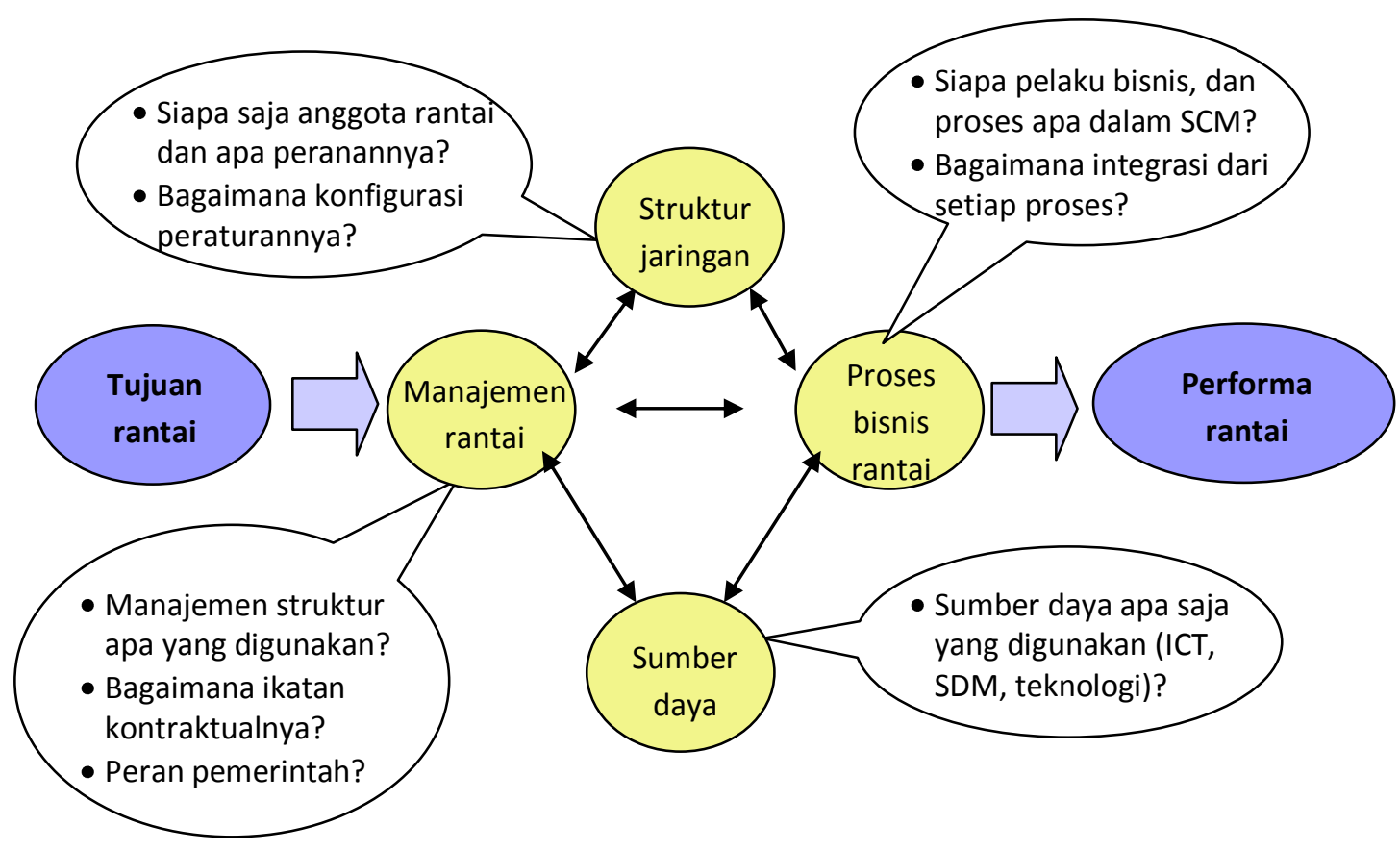

Gambar 2. Kerangka analisis deskriptif manajemen rantai pasokan

\section{Analisis Nilai Tambah}

Nilai tambah adalah selisih antara biaya input dan nilai output. Nilai tambah sepanjang rantai suplai dapat berupa perubahan wujud barang yang bertambah dan dapat pula tidak berwujud dilihat dari tambahan jasa yang diberikan. Nilai tambah adalah semua nilai tambah yang diciptakan pada tahap tertentu oleh faktor-faktor produksi, termasuk nilai tambah yang nyata melalui transformasi bahan baku, tenaga kerja dan modal, serta nilai tambah tidak berwujud melalui modal intelektual (penggunaan aset pengetahuan) dan pertukaran hubungan (yaitu membangun hubungan kerja sama). Menurut Hayami et al (1987), nilai tambah yang nyata dipengaruhi oleh faktor teknis (kapasitas produksi, jumlah bahan baku yang digunakan dan tenaga kerja) dan faktor pasar (harga output, upah tenaga kerja, harga bahan baku, dan nilai input lain), yang dapat dirumuskan sebagai berikut:

$$
\text { Nilai-Tambah- }=f\{K, B, T, U, H, h, L\}
$$

\section{Dimana:}

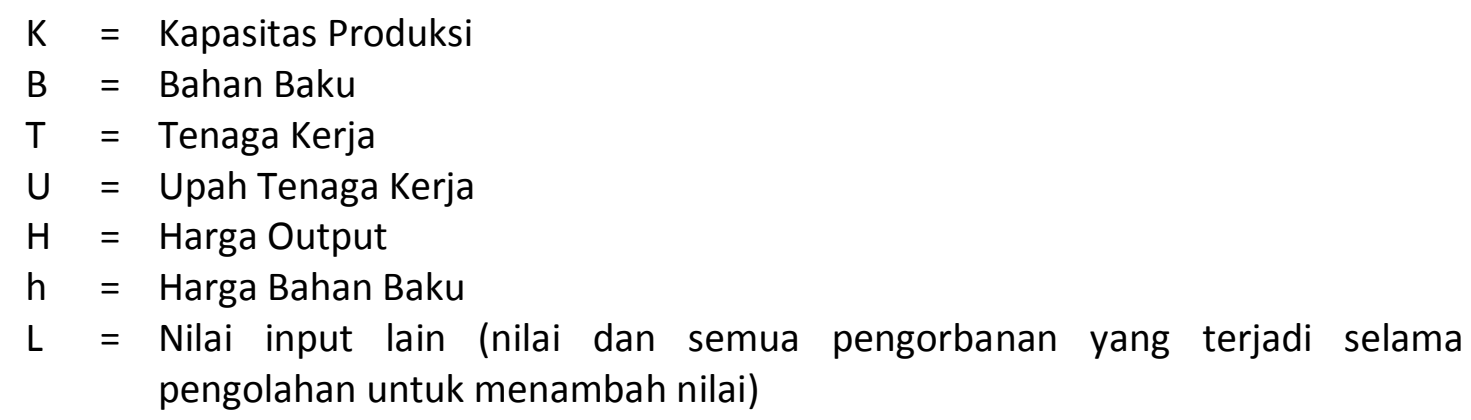




\section{ANP}

Metode ANP digunakan untuk menghitung bobot kinerja rantai pasok dengan memperhatikan tingkat ketergantungan antar kelompok atau cluster. Metode ini dimulai dengan pembuatan konstruksi model yang akan dievaluasi dan menentukan satu set lengkap jaringan kelompok (komponen) dan elemen-elemen yang relevan dengan tiap kriteria kontrol. Selanjutnya dilakukan penilaian dan perbandingan berpasangan dengan menggunakan skala perbandingan fundamental seperti pada Tabel 2.

Tabel 2. Skala perbandingan fundamental

\begin{tabular}{|c|c|c|}
\hline $\begin{array}{l}\text { Intensitas } \\
\text { Kepentingan }\end{array}$ & Definisi & Keterangan \\
\hline 1 & Sama Penting & Dua kegiatan berkontribusi sama terhadap tujuannya \\
\hline 3 & Sedikit Lebih Penting & $\begin{array}{l}\text { Pengalaman dan penilaian suatu kegiatan sedikit } \\
\text { berkontribusi atas yang lain }\end{array}$ \\
\hline 5 & Lebih Penting & $\begin{array}{l}\text { Pengalaman dan penilaian suatu kegiatan } \\
\text { berkontribusi sangat kuat atas yang lain, menunjukkan } \\
\text { dominasinya dalam praktek }\end{array}$ \\
\hline 7 & Sangat Lebih Penting & $\begin{array}{l}\text { Suatu kegiatan yang favorit berkontribusi sangat kuat } \\
\text { atas yang lain; menunjukkan dominasinya dalam } \\
\text { praktek }\end{array}$ \\
\hline 9 & Mutlak Lebih Penting & $\begin{array}{l}\text { Bukti yang menguntungkan satu kegiatan di atas yang } \\
\text { lain merupakan kemungkinan urutan afirmasi tertinggi }\end{array}$ \\
\hline $2,4,6,8$ & $\begin{array}{l}\text { Untuk kompromi antara } \\
\text { nilai-nilai di atas }\end{array}$ & $\begin{array}{l}\text { Kadang-kadang perlu melakukan interpolasi penilaian } \\
\text { kompromi secara numeric karena tidak ada istilah yang } \\
\text { tepat untuk menggambarkan hal tersebut }\end{array}$ \\
\hline
\end{tabular}

Perbandingan berpasangan dilakukan dengan membuat matriks perbandingan berpasangan, dengan nilai aij merepresentasikan nilai kepentingan relatif dari elemen pada baris (i) terhadap elemen pada kolom (j); misalkan aij = wi / wj. Jika ada $n$ elemen yang dibandingkan, maka matriks perbandingan $A$ didefinisikan sebagai :

$$
A=\left[\begin{array}{llll}
\frac{w_{1}}{w_{1}} & \frac{w_{1}}{w_{2}} & \ldots & \frac{w_{1}}{w_{n}} \\
\frac{w_{2}}{w_{1}} & \frac{w_{2}}{w_{2}} & \ldots & \frac{w_{2}}{w_{n}} \\
\frac{w_{n}}{w_{1}} & \frac{w_{n}}{w_{2}} & \ldots & \frac{w_{n}}{w_{n}}
\end{array}\right]=\left[\begin{array}{cccc}
1 & a_{12} & \ldots . & a_{1 n} \\
a_{21} & 1 & \ldots . & a_{2 n} \\
\ldots & \ldots . & \ldots & \ldots \ldots \\
a_{n 1} & a_{n 2} & \ldots . & 1
\end{array}\right] \ldots \ldots \ldots \ldots \ldots . . . . .(2)
$$

Setelah semua perbandingan berpasangan selesai dibuat, maka vektor bobot prioritas $(w)$ dihitung dengan mencari eigen vector dan menormalisasikannya.

$$
\begin{aligned}
& E V=\prod_{j=1}^{m} \frac{w_{i}}{w_{j}} \ldots \ldots \ldots \ldots \ldots \ldots \ldots \ldots(3 a) \\
& W i=\frac{E V_{i}}{\sum E V_{i}} \ldots \ldots \ldots \ldots \ldots \ldots \ldots \ldots \ldots \ldots \ldots \ldots \ldots \ldots \ldots \ldots \ldots \\
&
\end{aligned}
$$

Indeks Konsistensi/Consistency Index (Cl) dan Consistency Ratio (CR) dari matriks perbandingan berpasangan dapat dihitung dengan rumus : 


$$
\mathrm{CI}=\frac{\lambda \max -n}{n-1}, C R=\frac{\mathrm{CI}}{\mathrm{RCI}}
$$

Jika CR $<0.1$ maka penilaian dianggap konsisten.

Vektor prioritas yang berasal dari matriks perbandingan berpasangan dimasukkan sebagai sub kolom dari kolom yang sesuai pada supermatriks. Supermatriks merepresentasikan prioritas pengaruh dari elemen di sebelah kiri matriks terhadap elemen di atas matriks. Di bawah ini merupakan struktur umum dari supermatriks.

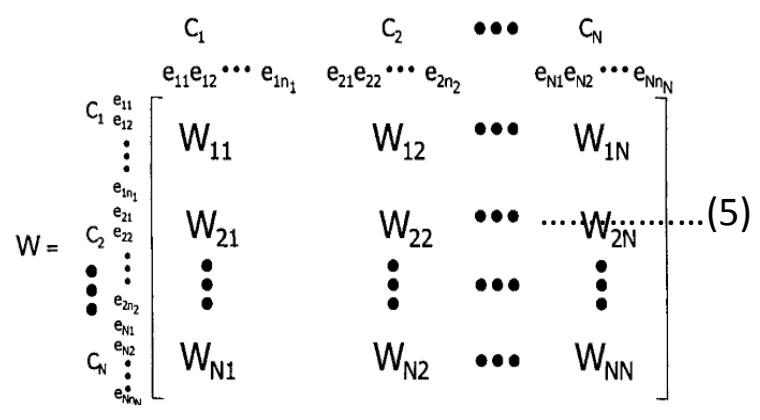

Masing-masing kolom dalam Wij adalah eigen vector yang menunjukkan kepentingan dari elemen pada komponen ke-i dari jaringan pada sebuah elemen pada komponen ke-j. Beberapa masukan yang menunjukkan hubungan nol pada elemen mengartikan tidak terdapat kepentingan pada elemen tersebut. Jika hal tersebut terjadi maka elemen tersebut tidak digunakan dalam perbandingan berpasangan untuk menurunkan eigen vector. Jadi yang digunakan adalah elemen yang menghasilkan nilai kepentingan bukan nol (Saaty 2006). Bobot yang diperoleh digunakan untuk membobot elemen-elemen pada blok-blok kolom (cluster) yang sesuai dari supermatriks, yang akan menghasilkan weighted supermatrix yang juga stokastik.

\section{Hasil dan Pembahasan}

III.1. Gambaran Umum Rantai Pasok

Rantai pasokan ini terdiri atas mitra tani, PT SSN, dan ritel serta pasar tradisional. Adapun aktivitas yang mereka lakukan dapat dilihat pada Tabel 3. Pola aliran dalam rantai pasok ini terdiri atas tiga jenis yaitu barang, uang, dan informasi. Aliran barang dimulai dari petani sampai ke konsumen akhir, sedangkan aliran uang sebaliknya. Adapun aliran informasi yang beredar di rantai pasok ini meliputi perencanaan yang dilakukan oleh perusahaan. 
Tabel 3. Anggota rantai pasok pepaya Calina

\begin{tabular}{llll}
\hline \multicolumn{1}{c}{ Tingkat } & \multicolumn{1}{c}{ Anggota } & \multicolumn{1}{c}{ Proses } & \multicolumn{1}{c}{ Aktivitas } \\
\hline Supplier & Mitra tani & $\begin{array}{l}\text { Pembudidayaan, } \\
\text { penjualan }\end{array}$ & $\begin{array}{l}\text { Melakukan penanaman pepaya Calina, } \\
\text { penjualan ke processor }\end{array}$ \\
\hline Processor & PT SSN & $\begin{array}{l}\text { Pembelian, pemeraman, } \\
\text { penyimpanan, penjualan, } \\
\text { pengiriman, pengemasan }\end{array}$ & $\begin{array}{l}\text { Melakukan pembelian dari mitra tani, } \\
\text { dan mengirimnya ke pasar tujuan } \\
\text { sesuai spesifikasi produk }\end{array}$ \\
\hline Pasar & Ritel dan Pasar & Pembelian, penjualan & $\begin{array}{l}\text { Melakukan pembelian pepaya Calina } \\
\text { dari PT. SSN dan menjual ke konsumen } \\
\text { tradisonal }\end{array}$ \\
& & & akhir \\
\hline
\end{tabular}

Kualitas produk pepaya Calina dalam rantai pasok ini dikelompokkan menjadi dua seperti yang ditunjukkan pada Tabel 4. Tujuan pasar dari produk pepaya Calina rantai pasokan ini adalah grade A untuk ritel dan grade B untuk pasar tradisional. Semula pasar tujuan rantai pasok ini hanya ritel, namun disebabkan tingginya persaingan menyebabkan rantai pasok ini memutuskan untuk mulai memasuki pasar tradisional.

Tabel 4. Spesifikasi grade pepaya Calina

\begin{tabular}{|c|c|c|c|c|c|}
\hline Kualitas & $S$ & sifikasi & Bobot & Harga Beli & Harga Jual \\
\hline Grade A & $\begin{array}{l}\text { 1. Daging matang } \\
\text { merah oranye }\end{array}$ & $\begin{array}{l}\text { 1. Bentuk proporsional } \\
\text { 2. Kadar maksimal } \\
\text { bruising dan sunburn } \\
5 \%\end{array}$ & $0.7-1$ & 2500 & 8000 \\
\hline Grade B & $\begin{array}{l}\text { 1. Kulit kuning } \\
\text { merata }\end{array}$ & $\begin{array}{l}\text { 1. Kelainan bentuk } \\
\text { 2. Kadar maksimal } \\
\text { bruising dan sunburn } \\
20 \%\end{array}$ & $1.1-1.7$ & 2500 & 6500 \\
\hline
\end{tabular}

Rantai pasok ini terkait dengan berbagai sumberdaya meliputi sumberdaya fisik, teknologi, manusia, dan permodalan. Sumberdaya fisik terdiri atas jalan dan sistem irigasi yang masih belum optimal, sedangkan sumberdaya teknologi baru sebatas pada pengujian pestisida oleh PT. Sucofindo dan pemeraman dengan metode ethrel oleh pihak perusahaan. Untuk sumberdaya manusia diberikan upah sesuai dengan Upah Minimum Regional (UMR) dan untuk sumberdaya permodalan budidaya ditanggung sepenuhnya oleh petani, sedangkan untuk pengolahan dan pendistribusian produk dilakukan oleh perusahaan. Pihak ritel dan pasar tradisional hanya mengeluarkan biaya untuk sewa tempat.

Untuk mendapatkan manajemen rantai pasokan yang baik, maka diperlukan kriteria-kriteria untuk pemilihan mitra. Kriteria-kriteria tersebut ditunjukkan pada Tabel 5. Kriteria-kriteria pemilihan mitra ini dibutuhkan agar kontrak yang sudah disepakati dapat ditaati oleh semua pihak dalam rantai pasok. Kesepakatan kontraktual yang ada di rantai pasok ini meliputi perusahaan dengan ritel saja, untuk kerjasama antara petani dan perusahaan serta perusahaan dan pasar tradisional hanya terikat oleh pendekatan personal, teknis, dan pasar. Isi kontrak antara perusahaan dan ritel adalah mengenai sistem pembayaran yang berupa kredit dan kualitas produk yang 
dipesan. Antara petani dan perusahaan meski tidak terikat kontrak namun perusahaan tetap menargetkan produksi sebesar 20 ton per minggu, walau jumlah yang baru bisa dipenuhi berkisar 15 sampai 18 ton per minggu.

Tabel 5. Kriteria-kriteria pemilihan mitra

\begin{tabular}{ll}
\hline \multicolumn{1}{c}{ Petani } & \multicolumn{1}{c}{ Perusahaan } \\
\hline $\begin{array}{l}\text { 1. Memproduksi pepaya Calina yang sesuai } \\
\text { dengan spesifikasi }\end{array}$ & 1. Membayar langsung kepada petani \\
2. Mampu memasok secara kontinu & $\begin{array}{l}\text { 2. Mampu memasok produk papaya Calina ke } \\
\text { ritel secara kontinu }\end{array}$ \\
3. Sanggup mengirim produk sesuai jadwal & 3. Menjaga kualitas produknya \\
\hline \multicolumn{1}{c}{ Ritel } & \multicolumn{1}{c}{ Pasar Tradisional } \\
\hline $\begin{array}{l}\text { 1. Memilki performa penjualan baik } \\
\text { 2. Menaati kontrak }\end{array}$ & 1. Lokasi strategis \\
3. Terletak di lokasi strategis & \\
4. Memiliki fasilitas penjualan baik &
\end{tabular}

Seperti pada bisnis yang lain, rantai pasok pepaya Calina pun menghadapi berbagai seperti risiko operasional, risiko kerjasama, risiko lingkungan dan kebijakan, serta risiko pasar yang dalam perjalanannya apabila tidak diatasi dengan baik mampu menghambat pengembangan rantai pasok. Hambatan tersebut meliputi petani yang sering mengalami kesulitan modal, biaya transportasi yang tinggi, lahan yang sering mengalami kekeringan sepanjang bulan Juli sampai September, tingginya turn over staff di perusahaan, penanganan pasca panen yang belum maksimal, adanya petani yang tidak memenuhi komitmen disebabkan belum adanya ikatan kontrak antara petani dengan perusahaan.

\section{III.2. Analisis Nilai Tambah Rantai Pasok Pepaya Calina}

Tujuan dari analisis nilai tambah adalah untuk mengukur balas jasa yang diterima pelaku sistem dan kesempatan kerja yang dapat diciptakan oleh sistem komoditas.

\section{Keuntungan Petani/Mitra Tani}

Mitra tani pepaya Calina tidak melakukan kegiatan apapun setelah melakukan panen sehingga tidak ada pemberian nilai tambah seperti pengolahan dan pengemasan pada pepaya Calina. Besarnya pendapatan yang diperoleh oleh petani adalah selisih pengeluaran produksi pepaya Calina dikurangi dengan pendapatan hasil panen. Rata-rata mitra tani mendapatkan keuntungan sebesar $57.74 \%$ per musim tanam, serta harga pokok produksi per kilogram dari hasil panen adalah sebesar Rp 1056.48 dengan asumsi bahwa petani menanam pepaya Calina sebanyak 1200 bibit per musim tanam. Apabila petani menanam pepaya Calina sebanyak 1200 bibit, maka petani akan menghasilkan $43200 \mathrm{~kg}$ pepaya Calina yang terbagi menjadi grade A untuk Sunpride dan B untuk Sunfresh.

2. Nilai Tambah Perusahaan (PT SSN)

Nilai tambah dihitung berdasarkan dua produk Pepaya Calina yang dipasarkan PT SSN terdiri atas Sunpride dan Sunfresh. Sunpride ditujukan untuk pasar ritel, sementara Sunfresh untuk pasar tradisional. Pengolahan pepaya Calina merek 
Sunpride menghasilkan nilai tambah sebesar Rp 2840 per kilogram, dengan rasio nilai tambah terhadap nilai pendapatan sebesar $50.7 \%$. Hasil perhitungan ini juga dapat menunjukkan persentase pangsa tenaga kerja. Persentase pangsa tenaga kerja yang dihasilkan perusahaan melalui produk Sunpridenya adalah sebesar $16 \%$. Hal ini berarti bahwa $16 \%$ dari nilai tambah merupakan pendapatan tenaga kerja yang harus dibayarkan oleh perusahaan. Sementara untuk pepaya Sunfresh dengan harga output sebesar Rp 6500 per kilogram menghasilkan nilai tambah sejumlah 3250.38 dengan rasio 55.56\%. Pangsa tenaga kerja yang dihasilkan oleh perusahaan dengan merek Sunfresh adalah $73.84 \%$. Hal ini berarti bahwa $73.84 \%$ dari nilai tambah merupakan pendapatan tenaga kerja yang harus dibayarkan oleh perusahaan (Tabel 6).

Tabel 6. Analisis nilai tambah di tingkat PT SSN

\begin{tabular}{|c|c|c|c|}
\hline \multirow{2}{*}{ No } & \multirow{2}{*}{ Variabel } & \multicolumn{2}{|c|}{ Nilai } \\
\hline & & Sunpride & Sunfresh \\
\hline \multicolumn{4}{|c|}{ Output, Input, Harga } \\
\hline 1 & Output (Kg/minggu) & 10500 & 2700 \\
\hline 2 & Bahan baku (Kg/minggu) & 15000 & 3000 \\
\hline 3 & Tenaga kerja langsung (HOK) & 30 & 30 \\
\hline 4 & Faktor konversi & 0.7 & 0.9 \\
\hline 5 & Koefisien tenaga kerja langsung (HOK/kg) & 0.002 & 0.01 \\
\hline 6 & Harga output (Rp/kg) & 8000 & 6500 \\
\hline 7 & Upah tenaga kerja langsung (Rp/HOK) & 240000 & 240000 \\
\hline \multicolumn{4}{|c|}{ Penerimaan dan Keuntungan } \\
\hline 8 & Harga bahan baku (Rp/kg) & 2500 & 2500 \\
\hline 9 & Harga input lain (Rp/kg) & 260 & 99.62 \\
\hline \multicolumn{4}{|c|}{ Penerimaan dan Keuntungan } \\
\hline 10 & Nilai output (Rp/kg) & 5600 & 5850 \\
\hline \multirow[t]{2}{*}{11} & a. Nilai tambah (Rp/kg) & 2840 & 3250.38 \\
\hline & b. Rasio nilai tambah (\%) & 50.7 & 55.56 \\
\hline \multirow[t]{2}{*}{12} & a. Pendapatan tenaga kerja langsung ( $\mathrm{Rp} / \mathrm{kg})$ & 480 & 2400 \\
\hline & b. Pangsa tenaga kerja langsung (\%) & 16 & 73. 84 \\
\hline \multirow[t]{2}{*}{13} & a. Keuntungan (Rp/kg) & 2360 & 850.38 \\
\hline & b. Tingkat keuntungan (\%) & 42.1 & 14.54 \\
\hline \multicolumn{4}{|c|}{ Balas Jasa Pemilik Faktor Produksi } \\
\hline \multirow[t]{4}{*}{14} & Marjin (Rp/kg) & 3100 & 3350 \\
\hline & a. Pendapatan tenaga kerja langsung (\%) & 15.5 & 71.64 \\
\hline & b. Sumbangan input lain (\%) & 8.4 & 7.76 \\
\hline & c. Keuntungan perusahaan (\%) & 76.1 & 25.38 \\
\hline
\end{tabular}

3. Nilai Keuntungan Ritel dan Pasar Tradisional

Pasar tradisional dengan harga output pepaya Sunfresh sebesar Rp 8000 per kilogram mendapatkan rasio nilai tambah sebesar $16.56 \%$ dan pangsa pendapatan tenaga kerja sejumlah 20.13\%. Hal ini berarti bahwa $20.13 \%$ dari nilai tambah merupakan pendapatan tenaga kerja yang harus dibayarkan oleh pasar tradisional (Tabel 7). 
Tabel 7. Nilai tambah pepaya Calina Sunfresh di tingkat pasar tradisional

\begin{tabular}{|c|c|c|}
\hline No & Variabel & Nilai \\
\hline \multicolumn{3}{|c|}{ Output, Input, Harga } \\
\hline 1 & Output (Kg/minggu) & 2700 \\
\hline 2 & Bahan baku (Kg/minggu) & 2700 \\
\hline 3 & Tenaga kerja langsung (HOK) & 3 \\
\hline 4 & Faktor konversi & 1 \\
\hline 5 & Koefisien tenaga kerja langsung (HOK/kg) & 0.001 \\
\hline 6 & Harga output (Rp/kg) & 8000 \\
\hline 7 & Upah tenaga kerja langsung (Rp/HOK) & 240000 \\
\hline \multicolumn{3}{|c|}{ Penerimaan dan Keuntungan } \\
\hline 8 & Harga bahan baku (Rp/kg) & 6500 \\
\hline 9 & Harga input lain (Rp/kg) & 175 \\
\hline 10 & Nilai output (Rp/kg) & 8000 \\
\hline \multirow[t]{2}{*}{11} & a. Nilai tambah (Rp/kg) & 1325 \\
\hline & b. Rasio nilai tambah (\%) & 16.56 \\
\hline \multirow[t]{2}{*}{12} & a. Pendapatan tenaga kerja langsung (Rp/kg) & 266.67 \\
\hline & b. Pangsa tenaga kerja langsung (\%) & 20.13 \\
\hline \multirow[t]{2}{*}{13} & a. Keuntungan (Rp/kg) & 1058.3 \\
\hline & b. Tingkat keuntungan (\%) & 13.23 \\
\hline \multicolumn{3}{|c|}{ Balas Jasa Pemilik Faktor Produksi } \\
\hline \multirow[t]{4}{*}{14} & Marjin (Rp/kg) & 1500 \\
\hline & a. Pendapatan tenaga kerja langsung (\%) & 0.18 \\
\hline & b. Sumbangan input lain (\%) & 11.67 \\
\hline & c. Keuntungan perusahaan (\%) & 70.56 \\
\hline
\end{tabular}

Nilai keuntungan yang dihasilkan ritel hanya sebatas pada perpindahan tempat yang meningkatkan harga pepaya Sunpride per kilogram dari harga Rp 8000 menjadi Rp 10 950. Ini berarti persentase nilai keuntungan ritel sebesar 36\%.

\section{Distibusi Nilai Tambah pada Rantai Pasok Pepaya Calina}

Untuk perhitungan distribusi pepaya Sunpride seperti yang ditunjukkan pada Tabel 8 dan 9, petani mendapatkan rasio marjin terkecil (2.7\%), padahal petani menanggung risiko yang paling besar berupa gagal panen. Ditambah lagi petani juga mengeluarkan biaya dengan rasio tertinggi dalam rantai pasok yaitu sebesar $18.1 \%$. Sementara perusahaan mendapatkan rasio marjin terbesar (64.3\%) dan rasio biaya terkecil kedua (17.9\%). Hal ini mungkin disebabkan tingginya perbedaan harga jual dan beli perusahaan sebesar Rp 5500 untuk Sunpride. Selanjutnya ritel sebagai pelaku yang tidak mengeluarkan biaya apapun selain biaya pembelian menyebabkan rasio biaya yang ditanggungnya sebesar $0 \%$. Hal ini disebabkan bila ada barang yang rusak ataupun tidak laku terjual, maka akan dikembalikan kepada perusahaan tanpa perlu membayar. Sementara untuk pemasaran di ritel, perusahaan menempatkan sales promotion untuk promosi dengan pencicipan buah potong.

Tabel 8. Distribusi biaya dan marjin pepaya Calina Sunpride

\begin{tabular}{|c|c|c|c|c|}
\hline No & Pelaku & $\begin{array}{c}\text { Total Biaya } \\
\text { (Rp) }\end{array}$ & $\begin{array}{c}\text { Harga Output } \\
\text { (Rp) }\end{array}$ & $\begin{array}{c}\text { Marjin } \\
\text { (Rp) }\end{array}$ \\
\hline 1 & Petani & 2256.5 & 2500 & 243.5 \\
\hline 2 & Perusahaan & 2240 & 8000 & 5760 \\
\hline 3 & Ritel & 8000 & 10950 & 2950 \\
\hline & Total & 12496.5 & 21450 & 8953.5 \\
\hline
\end{tabular}


Tabel 9. Rasio biaya dan marjin pepaya Calina Sunpride

\begin{tabular}{llccc}
\hline No & Pelaku & $\begin{array}{c}\text { Rasio Biaya } \\
\text { (\%) }\end{array}$ & $\begin{array}{c}\text { Rasio Marjin } \\
\text { (\%) }\end{array}$ & $\begin{array}{c}\text { Rasio Marjin/Biaya } \\
\text { (\%) }\end{array}$ \\
\hline 1 & Petani & 18.1 & 2.7 & 10.8 \\
2 & Perusahaan & 17.9 & 64.3 & 257 \\
3 & Ritel & $* 0$ & 32.9 & 36.875 \\
\hline
\end{tabular}

*Keterangan: disebabkan ritel tidak mengeluarkan biaya apapun selain biaya pembelian.

Untuk perhitungan distribusi pepaya Sunfresh seperti yang ditunjukkan pada Tabel 10 dan 11, urutan rasio biayanya adalah petani dengan angka 20.2\%, kemudian perusahaan sebesar 20.05\%, dan pasar tradisional 59.75\%. Pasar tradisional mengeluarkan biaya transpor, sewa lapak, dan membayar tenaga kerja sebesar 175. Tabel 11 menunjukkan bahwa rasio marjin petani hanya sebesar $4.18 \%$ tidak sebanding dengan rasio biaya yang telah dikeluarkan. Sementara untuk perusahaan rasio marjinnya menempati urutan terbesar dengan nilai $73.09 \%$ dan pasar tradisional menyusul setelahnya sebesar $22.73 \%$.

\begin{tabular}{llccc}
\multicolumn{4}{l}{ Tabel } & \multicolumn{4}{c}{ 10. Distribusi biaya dan marjin pada rantai pasok pepaya Calina Sunfresh } \\
\hline No & \multicolumn{1}{c}{ Pelaku } & $\begin{array}{c}\text { Total Biaya } \\
\text { (Rp) }\end{array}$ & $\begin{array}{c}\text { Harga Output } \\
\text { (Rp) }\end{array}$ & $\begin{array}{c}\text { Marjin } \\
\text { (Rp) }\end{array}$ \\
\hline 1 & Petani & 2256.5 & 2500 & 243.5 \\
2 & Perusahaan & 2240 & 6500 & 4260 \\
3 & Pasar Tradisional & 6625 & 8000 & 1325 \\
& Total & 11171.5 & 17500 & 5828.5 \\
\hline
\end{tabular}

Tabel 11. Rasio biaya dan marjin pada rantai pasok pepaya Calina Sunfresh

\begin{tabular}{llccc}
\hline No & \multicolumn{1}{c}{ Pelaku } & $\begin{array}{c}\text { Rasio Biaya } \\
\mathbf{( \% )}\end{array}$ & $\begin{array}{c}\text { Rasio Marjin } \\
\mathbf{( \% )}\end{array}$ & $\begin{array}{c}\text { Rasio Marjin Biaya } \\
(\%)\end{array}$ \\
\hline 1 & Petani & 20.2 & 4.18 & 10.79 \\
2 & Perusahaan & 20.05 & 73.09 & 190.18 \\
3 & Pasar tradisional & 59.75 & 22.73 & 19.85 \\
\hline
\end{tabular}

Berdasarkan analisis distribusi nilai tambah dapat ditunjukkan perusahaan adalah pihak yang paling diuntungkan dalam rantai pasok ini dengan nilai rasio marjinnya menempati urutan terbesar baik untuk produk pepaya Calina Sunpride maupun produk pepaya Calina Sunfresh. Sementara ritel menempati urutan kedua dengan nilai rasio marjin/biayanya sebesar $36.875 \%$ padahal ritel tidak memberikan kontribusi nilai tambah apapun selain perpindahan tempat yang itupun biayanya ditanggung oleh perusahaan. Petani sebagai produsen dalam rantai pasok ini harus memperoleh rasio marjin/biaya dengan nilai hanya sebesar $10.8 \%$ pada produk pepaya Sunpride dan $10.79 \%$ untuk produk pepaya Sunfresh. Padahal petani menanggung risiko besar seperit gagal panen dan harus menunggu panen selama kurang lebih delapan bulan berbeda dengan pelaku lain dalam rantai pasok yang mampu mendapatkan keuntungan perminggu. Kemudian pasar tradisional menjadi pihak yang menempati urutan terakhir dalam rasio marjin biaya dengan angka $19.85 \%$ disebabkan harga pepaya Sunfresh yang lebih rendah serta pasar tradisional harus menanggung barangbarang yang cacat dan tidak diperbolehkan mengembalikannya pada perusahaan seperti yang terjadi pada kasus ritel. 


\section{III.3. Penentuan Metrik Kinerja Rantai Pasok}

Manajemen rantai pasokan berkelanjutan (SSCM) menurut Carter dan Rogers (2008) dapat didefinisikan sebagai manajemen rantai pasokan strategis, integrasi transparan dan pencapaian tujuan sosial, lingkungan, dan ekonomi organisasi dalam koordinasi sistematis kunci proses bisnis antar-organisasi untuk meningkatkan kinerja ekonomi jangka panjang perusahaan individu dan rantai pasokan. Manajemen rantai pasokan yang berkelanjutan mensyaratkan bahwa kriteria keberlanjutan dipenuhi dengan tetap menjaga daya saing melalui memenuhi kebutuhan pelanggan (Seuring dan Müller 2008).

Kerangka ANP dalam perancangan metrik pengukuran kinerja dapat diklasifikasi dalam struktur ini terdiri dari 3 cluster:

Cluster 1 : Dimensi yang berkenaan dengan rantai pasok berkelanjutan, yaitu tidak hanya ekonomi dan sosial saja, melainkan lingkungan juga. Agar usaha rantai pasok ini dapat terus berjalan ke depannya.

Cluster 2 : Aktor yang berperan dalam rantai nilai komoditas pepaya Calina terdiri atas: Petani, perusahaan, ritel, dan pasar tradisional.

Cluster 3 : Indikator kinerja untuk mengevaluasi kinerja rantai pasok pepaya Calina adalah penggunaan pestisida, pembuangan limbah, reuse/recycle material, keefektivan kompensasi pekerja, nilai tambah, kualitas, dan jumlah mitra tani.

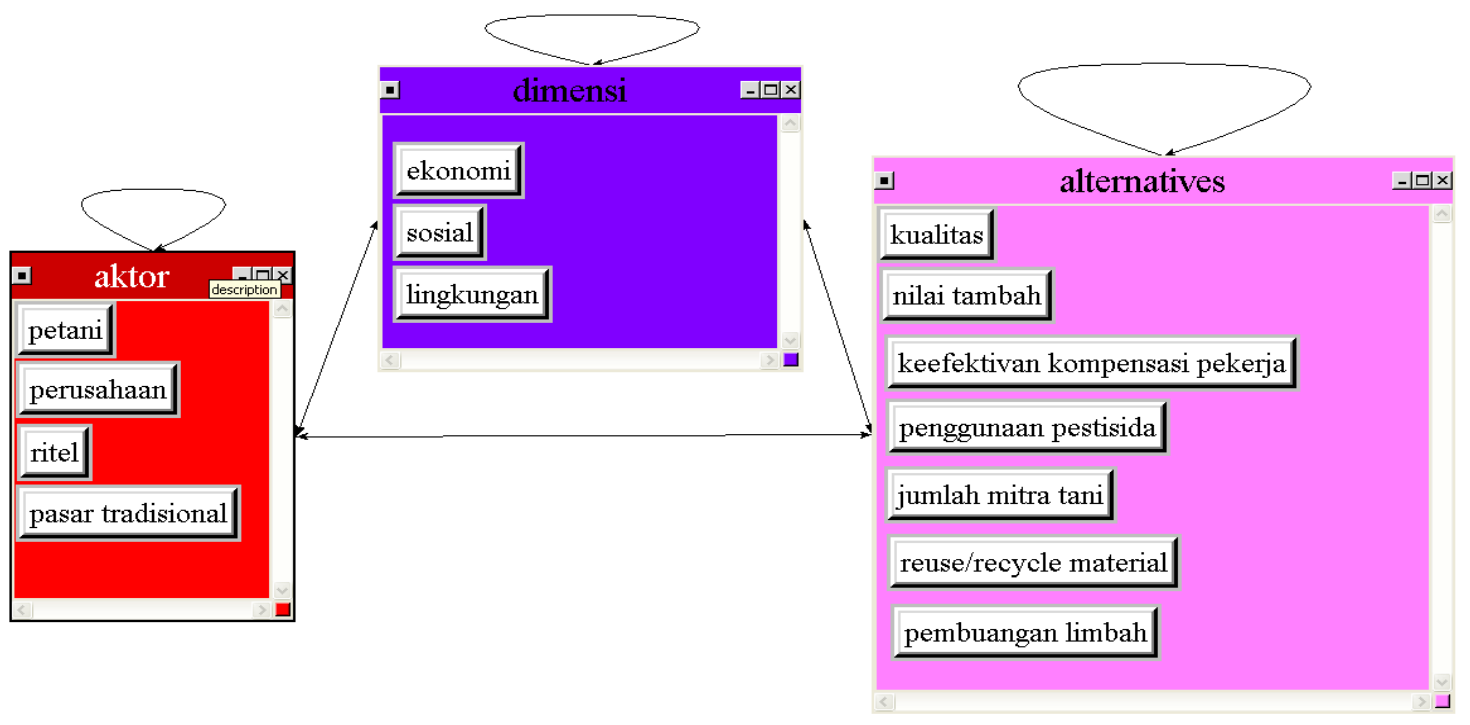

Gambar 3. Kerangka umum ANP

\section{Prioritas Klaster Dimensi}

Dimensi ekonomi menjadi dimensi yang paling berpengaruh pada keberlangsungan rantai pasok berkelanjutan pepaya Calinaini (Gambar 4). Dalam iklim ekonomi saat ini, keberhasilan ekonomi perusahaan yang terjalin tidak hanya dengan tindakan sosial dan lingkungan tetapi juga dengan para pemasoknya (Accenture 2008). Oleh karena itu, manajemen rantai pasokan yang berkelanjutan sangat penting. Melestarikan lingkungan dapat dilihat sebagai beban bagi perusahaan. Meskipun 
terkadang solusi berkelanjutan tampaknya tidak menguntungkan, stakeholder semakin menuntut bahwa perusahaan harus mengelola isu-isu lingkungan dan sosial mereka (Carter dan Easton 2011), khususnya di bawah ekonomi, peraturan, dan tekanan konsumen (Srivastava dan Srivastava 2006; Krikke et al 2003). Saat ini, konsumen menuntut lebih banyak produk ramah lingkungan dan melakukan proses daur ulang (Krikke et al 2003; Chan et al 2010).

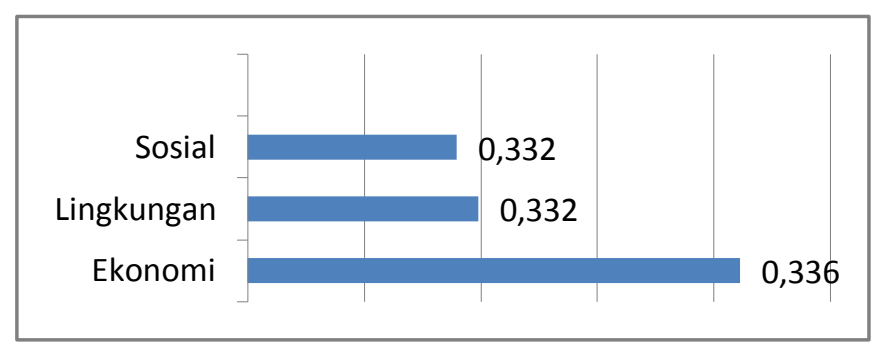

Gambar 4. Prioritas klaster dimensi

Para pelaku di sepanjang rantai pasok pepaya Calina sejauh ini mendapatkan pembagian keuntungan yang merata sesuai dengan risiko yang ditanggungnya. Petani selaku produsen yang memegang peran penting dalam rantai pasok pepaya Calina mendapatkan keuntungan sebesar $57.74 \%$ dari penjualan. Sementara perusahaan sebagai pihak processor memperoleh laba sebesar $45.01 \%$ dari penjualan pepaya Calina merek Sunpride dan $14.54 \%$ dari penjualan pepaya Calina merek Sunfresh. Selanjutnya pihak ritel dan pasar tradisional sebagai konsumen mendapatkan keuntungan sebesar 36\% dan $7 \%$ dari penjualannya.

Pelaku di dalam rantai pasok pepaya Calina dengan tingkat keuntungan tersebut mampu memenuhi aspek sosialnya dengan memberikan gaji sesuai UMR baik kepada petani di kebun maupun tenaga outsourcing serta sales promotion di ritel. Mengenai lingkungan, perhatian pelaku rantai pasok ini baru sebatas pada penyewaan jasa PT. Sucofindo untuk pengujian pestisida secara berkala agar tidak melebihi ambang batas aman konsumsi dan belum sampai ke tahap pengembangan pertanian organik.

\section{Prioritas Klaster Aktor}

Rantai pasok pepaya Calina ini disokong oleh pelaku (aktor) yang terdiri atas petani sebagai produsen, perusahaan sebagai processor, dan ritel serta pasar tradisional sebagai pasar. Petani menjadi aktor yang menempati posisi teratas dalam pengaruhnya terhadap rantai pasok ini disebabkan pentingnya peran yang dipegangnya dalam budidaya pepaya (Gambar 5). Meskipun perencanaan tanam dilakukan oleh perusahaan, urusan produksi seluruhnya diserahkan kepada petani mulai dari pembibitan sampai pemanenan. Hal inilah yang menyebabkan petani menjadi penentu utama kuantitas dan kualitas pepaya Calina rantai pasok ini secara keseluruhan. Dalam menjalankan tugasnya, petani juga menanggung risiko yaitu petani sering memaksakan untuk menanam di lokasi yang tidak sesuai, seperti ketinggiannya yang kurang mencukupi, sehingga sering berakibat banjir atau kekeringan pada lahan tersebut. Selain itu juga risiko dalam proses pengiriman hasil panen ke perusahaan, dimana sering terjadi loss volume sebesar $20 \%$. 


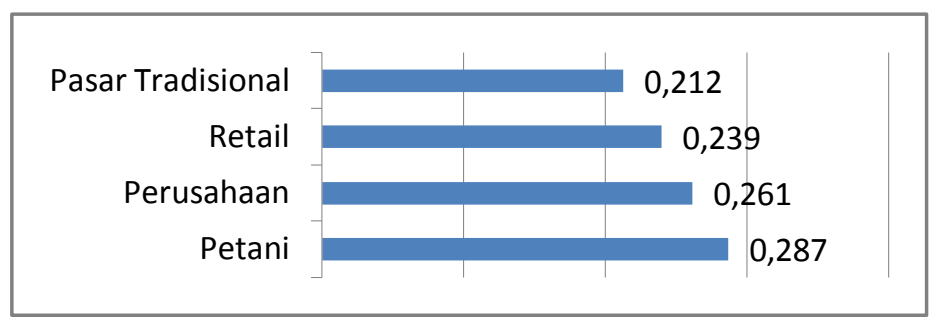

Gambar 5. Prioritas klaster aktor

Perusahaan menduduki urutan kedua dalam prioritas klaster aktor disebabkan fungsinya yang kompleks. Perusahaan menjadi perantara antara petani dengan pasar dan menanggung berbagai risiko. Risiko tersebut antara lain adanya pesaing dari banyaknya perusahaan seperti PT Mulia Raya/Green, PD Alam Megah, Caraka Farm, Tresma, PT Boga Tani, Puri Subagja Jatim, Gege Raja Buah, Ibana, PT Lentera, Havana Buah, dan CV Alam Agro Mandiri. Selain itu persaingan juga berasal dari komoditas buah lain seperti buah mangga. Perusahaan membeli semua hasil panen petani dan dilarang mengembalikan pepaya Calina yang sudah dibeli. Namun, perusahaan harus mau menerima barang return dan reject dari ritel. Barang return dan reject biasanya diterima perusahaan sebesar $10 \%$ dari penjualan. Hal ini disebabkan oleh turunnya kualitas pepaya yang mencapai level di bawah spesifikasi yang disepakati. Turunnya kualitas ini ditimbulkan oleh adanya goresan di pepaya akibat tidak digunakannya kaos tangan saat penyortiran dan kesalahan pengiriman produk pada pasar yang tidak sesuai sasaran. Risiko lain yang harus dihadapi perusahaan adalah fluktuasi harga dan pasokan di tingkat petani yang berkisar dari Rp 2500 sampai Rp 5200.

Ritel menyusul di urutan berikutnya dalam prioritas klaster aktor karena keuntungan yang didapatnya merupakan keuntungan yang terbesar kedua di dalam rantai pasok dengan risiko hanya berupa fluktuasi jumlah pasokan yang tergantung musim. Hal ini disebabkan tidak adanya klausula kuantitas dalam kontrak antara ritel dan perusahaan. Posisi terakhir ditempati pasar tradisional karena seperti ritelyang memiliki risiko kecil, pasar tradisional juga tidak memberikan nilai tambah apapun selain perpindahan tempat kepada pepaya Calina.

\section{Prioritas Klaster Indikator Kinerja}

Kualitas adalah indikator kinerja utama yang berpengaruh pada rantai pasokan pepaya Calina (Gambar 6). Berdasarkan Standar Nasional Indonesia (SNI 4230 : 2009) ketentuan mutu minimum yang harus dipenuhi oleh pepaya Calina adalah utuh, penampilan buah segar, padat (firm), layak konsumsi, bersih, bebas dari benda-benda asing yang tampak, bebas dari hama dan penyakit, bebas dari memar, bebas dari kerusakan akibat temperatur rendah dan atau tinggi, bebas dari kelembaban eksternal yang abnormal, bebas dari aroma dan rasa asing, serta tangkai buah panjangnya tidak lebih dari $3 \mathrm{~cm}$. 


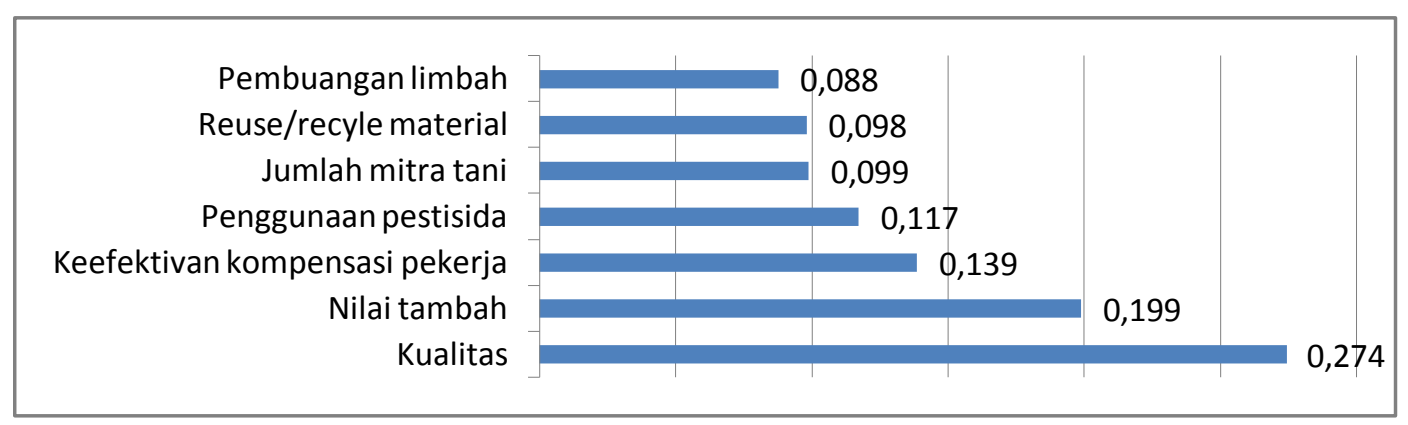

Gambar 6. Prioritas klaster indikator kinerja

Nilai tambah menjadi indikator berikutnya yang paling berkontribusi pada kinerja rantai pasok. Pengertian nilai tambah adalah selisih antara komoditas yang mendapatkan perlakuan pada tahap tertentu dengan nilai yang dikeluarkan selama proses berlangsung. Tujuan nilai tambah adalah untuk mengukur balas jasa yang diterima pelaku bisnis dan kesempatan kerja yang dapat diciptakan oleh sistem komoditas (Sudiyono 2002). Peningkatan nilai tambah dapat meliputi pengubahan bentuk, pemindahan tempat, maupun penyimpanan. Nilai tambah yang sudah diberikan kepada pepaya Calina dalam rantai pasok perusahaan adalah berupa penggradingan, penyortiran, pemeraman, pelabelan, pengubahan bentuk, penyimpanan, dan pengiriman.

Indikator kinerja ketiga yang menjadi fokus perhatian klaster adalah keefektivan kompensasi pekerja. Guide dan Van Wassenhove (2009) menyatakan bahwa sebagian besar penelitian tentang SSCM berfokus pada masalah teknis dan operasional. Namun Guide dan Van Wassenhoven (2009) mendukung bahwa harus diperpanjang perhatian penelitian di luar zona kenyamanan tradisional SSCM, dengan mengintegrasikan diantaranya yakni penghargaan manajerial untuk meningkatkan nilai dan kinerja dari SSCM. Meski kompensasi pekerja di sepanjang rantai pasok pepaya Calina ini sudah memenuhi Upah Minimum Kerja (UMK), namun tidak sebanding dengan pesaing. Inilah yang menyebabkan banyaknya turnover pegawai dari rantai pasok ini.

Penggunaan pestisida merupakan salah satu dari komponen biaya yang harus dipertimbangkan dalam pengukuran kinerja rantai pasok. Penggunaan pestisida yang digunakan dalam dosis aman memang mampu untuk menyuburkan dan memelihara tanaman dari hama serta penyakit. Namun bila dipakai berkepanjangan hal ini dapat menyebabkan hama dan penyakit kebal terhadap pestisida tersebut. Selain itu, pestisida dapat menimbulkan risiko pencemaran dan penyakit bagi orang yang mengkonsumsinya. Maka sebaiknya penggunaan pestisida ditiadakan karena selain mengurangi biaya produksi juga akan meningkatkan segmen pasar kepada konsumen yang peduli dengan gaya hidup sehat.

Penggunaan pestisida untuk pepaya Calina ditentukan berdasarkan musim, dimana untuk musim kemarau, pestisida diberikan setiap sebulan sekali sementara untuk musim hujan, pestisida diberikan seminggu sekali. Menurut Lee (2010) pengurangan penggunaan pestisida serta penggunaan drip irrigation (irigasi tetes) untuk pengairan dan nutrisi mampu meningkatkan kualitas tanaman dan melipatgandakan produktivitas hingga dua kali lipat. 
Jumlah mitra tani juga menjadi indikator kinerja yang tidak boleh dilupakan karena mempengaruhi melalui sisi pasokan serta produktivitas. Petani penghasil pepaya Calina dalam rantai pasok ini berasal dari Jasinga, Pasir Mukti, Tasikmalaya, dan Cilacap (Tabel 12).

Tabel 12. Mitra tani dalam rantai pasokan

\begin{tabular}{llcc}
\hline No & \multicolumn{1}{c}{ Daerah } & $\begin{array}{c}\text { Jumlah Petani } \\
\text { (orang) }\end{array}$ & $\begin{array}{c}\text { Jumlah Produksi per } \\
\text { Minggu }\end{array}$ \\
\hline 1 & Tasikmalaya dan Cilacap & 30 & 16 ton \\
2 & Jasinga & 26 & 3 ton \\
3 & Pasir Mukti & 1 & 1 ton \\
\hline
\end{tabular}

Metrik reuse/recycle material dan pembuangan limbah didasarkan pada hasil penelitian dar Hadiguna (2012). Reuse/recycle material digunakan untuk melindungi pepaya Calina dari bahaya fisik. Adapun reuse/recycle material yang digunakan dalam rantai pasok pepaya Calina ini adalah krat, spons, koran di tingkat perusahaan. Krat dan spons digunakan berkali kali, sedangkan koran maksimal digunakan untuk dua kali pemakaian. Untuk tingkat petani, satu pepaya menggunakan satu lembar koran. Sedangkan di tingkat perusahaan, satu pepaya dibungkus dengan setengah lembar koran.

Luketsi (2011) dalam penelitiannya menyatakan bahwa kemasan yang paling baik untuk mengurangi kerusakan mekanis pada saat transportasi pepaya IPB 9 (Calina) merupakan bahan pengisi cacahan kertas koran dan posisi penyusunan buah secara horizontal. Mengenai pembuangan limbah, Usaha Kecil dan Menengah (UKM) di sekitar perusahaan mengolah limbah dari pepaya Calina perusahaan yang reject dan return menjadi pupuk kompos.

\section{Kesimpulan}

Rantai pasokan pepaya Calina terdiri atas mitra tani, PT SSN, ritel atau pasar tradisional. Nilai tambah merupakan aspek penting yang mempengaruhi kinerja rantai pasok pepaya Calina karena menunjukkan kontribusi dari masing-masing anggota dalam menghantarkan kepuasan kepada konsumen. Perusahaan memberikan nilai tambah sebesar 53.58\% untuk merek Sunpride dan 55.56\% untuk merek Sunfresh. Sedangkan mitra tani dan pasar mendapatkan keuntungan sebesar $57.74 \%$, 36\% untuk ritel dan $7 \%$ untuk pasar tradisional.

Desain metrik pengukuran kinerja untuk rantai pasok pepaya Calina ditujukan untuk penerapan sustainable supply chain yang terdiri atas tiga cluster masing masing adalah dimensi, aktor, dan indikator. Indikator yang dirasa paling berpengaruh oleh para pakar untuk menentukan sustainable supply chain adalah kualitas. Hal ini disebabkan kualitas mampu menghantarkan kepuasan kepada konsumen dan dalam jangka panjang mampu menciptakan loyalitas konsumen, oleh karena itu petani menjadi pihak yang paling berpengaruh di dalam rantai pasok papaya Calina. 


\section{Daftar Pustaka}

Accenture. 2008. A New Era of Sustainability UN Global Compact Accenture CEO Study. [internet]. [diunduh 2013 Jun 25]. Tersedia pada: Http://www.accenture.com/ SiteCollectionDocuments/PDF/Accenture_A_New_Era_of_Sustainability_CEO_St udy.pdf

Carter CR, Easton PL. 2011. Sustainable supply chain management: evolution and future directions. International Journal of Physical Distribution and Logistics Management. 41(1): 46-62.DOI:10.1108/09600031111101420

Carter CR, Rogers DS. 2008. A framework of sustainable supply chain management: moving toward new theory. International Journal of Physical Distribution and Logistics Management. 38(5): 360-387.DOI:10.1108/09600030810882816

Chan HK, Yin S, Chan FTS. 2010. Implementing JIT philosophy to reverse logistics systems: a review. International Journal of Production Research. 48(21): 62936313.

Direktorat Jenderal Hortikultura. 2013. Departemen Pertanian. [Internet]. [diunduh 2013 Jan 20]. Tersedia pada: http://hortikultura.deptan.go.id.

Guide Jr VDR, Van Wassenhove LN 2009. The Evolution of Closed-Loop Supply Chain Research. Operations Research. 57(1): 10-18.DOI: 10.1287/opre.1080.0628

Hadiguna RA. 2012. Risk-Based Performance Prediction Model for Sustainable Palm Oil Supply Chain. Jurnal Teknik Industri. 14(1): 13-24.

Hayami Y, Kawagoe T, Morooka Y, Siregar M. 1987. Agricultural Marketing and Processing in Upland Java. A Perspective from a Sunda Village. Bogor (ID): The CPGRT Centre.

Krikke H, Bloemhof-Ruwaard J, Van Wassenhove LN. 2003. Concurrent product and closed-loop supply chain design with an application to refrigerators. International Journal of Production Research. 41(16): 3689-3719.

Lee H. 2010. Don't tweak your supply chain - rethink it from end to end. Harvard Business Review. 88(10): 63-69.

Luketsi WP. 2011. Pengaruh Perlakuan Bahan Pengisi Kemasan terhadap Mutu Fisik Buah Pepaya IPB 9 (Callina) Selama Transportasi [Skripsi]. Bogor [ID]: Institut Pertanian Bogor.

Saaty TL. 2001. Decision Making with Dependence and Feedback, The Analytical Network Process. Pennsylvania (US): University of Pittsburgh.

Seuring S, Müller M. 2008. From a literature review to a conceptual framework for sustainable supply chain management. Journal of Cleaner Production. 16 (15): 1699-1710.

Simchi-Levi D, Kaminsky P, Simchi-Levi E. 2007.Designing and Managing the Supply Chain; Concepts, Strategies, and Case Studies. Massachusets [US] : MIT pr.

[SNI] Standar Nasional Indonesia. 2009. SNI 4230: 2009 tentang Pepaya [Internet]. [diunduh 2013 Jan 16]. Tersedia pada: http://www.bsn.go.id. 
Srivastava SK, Srivastava RK. 2006. Managing product returns for reverse logistics. International Journal of Physical Distribution and Logistics Management. 36(7): 524-546.DOI:10.1108/09600030610684962.

Sudiyono A. 2002. Pemasaran Pertanian. Yogyakarta [ID] : UMM Press.

Vorst JGAJVD. 2006. Performance measurement in agri food supply-chain networks. An overview.Quantifying the agri-food supply chain[Internet]. [diunduh 2013 Jan 20]. Tersedia pada: library.wur.nl/frontis/quantifying_supply_chain/02_van _der_vorst.pdf.

Yakovieva N, Sarkis J, Sloan TW. 2009. Sustainable Benchmarking of Food Supply Chains. Working Paper No. 2009-02. Clark University George Perkins Marsh Institute [internet]. [diunduh 2013 Jun 20] Tersedia pada : http://www.clarku.edu/departments/marsh/news/WP2009-02.pdf. 